Biol. Stud. 2015: 9(3-4); 5-14 • DOI: https://doi.org/10.30970/sbi.0903.456

www.http://publications.Inu.edu.ua/journals/index.php/biology

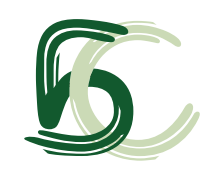

UDC: $616.72-002.77: 577.2: 576.32 / .36: 602.9$

\title{
ShRNA-MEDIATED KNOCKDOWN OF INTERLEUKIN-6 EXPRESSION RESCUES TUMOR NECROSIS FACTOR $\alpha$-INHIBITED OSTEOGENESIS IN MOUSE MESENCHYMAL PRECURSOR CELLS
}

\author{
Kh. V. Malysheva ${ }^{1,2}$, K. de Rooij ${ }^{3}$, C. W. G. M. Löwik ${ }^{3}$, \\ D. L. Baeten ${ }^{4}$, R. S. Stoika ${ }^{1}$, O. G. Korchynskyi ${ }^{1,3,4}$ \\ ${ }^{1}$ Institute of Cell Biology, NAS of Ukraine, 14/16, Drahomanov St., Lviv 79005, Ukraine \\ e-mail: olexkor@hotmail.com. \\ ${ }^{2}$ Insitute of Animal Biology, NAAS of Ukraine, 38, V. Stus St., Lviv 79034, Ukraine \\ ${ }^{3}$ Leiden University Medical Center, Leiden, The Netherlands \\ ${ }^{4}$ Academic Medical Center/University of Amsterdam, \\ Division of Clinical Immunology and Rheumatology, Amsterdam, The Netherlands
}

Rheumatoid arthritis (RA) is a severe autoimmune inflammatory disorder that strongly reduces a quality of patient's life due to its association with different morbidities and socioeconomic expenses. The etiology of the disease remains unknown. It has been demonstrated that interleukin-6 (IL-6), a target gene of tumor necrosis factor $\alpha$ (TNF $\alpha$ ) and interleukin $1 \beta$ (IL-1 $\beta$ ), plays a crucial role in the pathophysiology of RA. It is well known that bone morphogenetic protein (BMP)- and Wnt-involved pathways are key signaling mechanisms that induce and potentiate cartilage and bone formation and maintenance. We found that IL-6 similarly to TNF $\alpha$ inhibits activation of Wnt signaling pathway in primary human synoviocytes. In current study, we evaluated an impact of previously unrecognized negative interaction between the Wnt and IL-6 signaling pathways in skeletal tissues, as a possible major mechanism leading to age- and inflammation-related bone and joints destruction. It was found that shRNA-mediated knockdown of IL-6 mRNA significantly increased early hBMP2/7-induced osteogenesis and rescues it from the negative effect of TNF $\alpha$ in $\mathrm{C} 2 \mathrm{C} 12$ cells. It also intensified bone matrix mineralization in KS483 mouse mesenchymal precursor cells (MPC). Thus, IL-6 is an important mediator in the inhibition of osteoblast differentiation by the TNF $\alpha$, and knockdown of $I L-6$ expression partially rescues osteogenesis from the negative control of inflammation. The anti-osteoblastic effects of IL-6 are most likely mediated by its negative regulation of Wnt signaling pathway.

Keywords: rheumatoid arthritis, interleukin-6, osteogenesis, mesenchymal stem cells, Wnt signaling pathway.

\section{INTRODUCTION}

RA is a chronic systemic autoimmune inflammatory disorder that affects up to $1.8 \%$ of adult population of the world. This disease has a significant medical and social impact,

ISSN 1996-4536 (print) • ISSN 2311-0783 (on-line) • Біологічні Студії / Studia Biologica • 2015 • Том 9/№3-4 • С. 5-14 
since the absence of the effective treatment rapidly leads to reduced quality of patients' life and results in disability and even morbidity. RA may affect many tissues and organs, but primarily it attacks the synovium of joints. The process induces synovitis, synovial hyperplasia with neovascularization, and an excess of synovial fluid causing joint swelling, stiffness, and pain. That leads to a destruction of articular cartilage and multiple erosions into adjacent bones [8]. Although RA has been a subject of numerous investigations, the cause of the disease is still unknown and its etiology and pathogenesis remain poorly understood [22].

Multiple cytokines regulate a broad range of inflammatory processes implicated in the RA pathogenesis. An imbalance between the pro- and anti-inflammatory cytokine activities favors the induction of autoimmunity, chronic inflammation, and thereby damage of RA patient's joints [21]. TNF $\alpha$, IL-1 $\beta$ and IL-6 play primary roles in the RA pathogenesis as well as in other inflammatory diseases [8, 11].

IL-6 can promote synovitis and joint destruction by stimulating neutrophil migration, osteoclast maturation and pannus formation. IL- 6 may also be mediating numerous systemic manifestations of RA including joint erosions developing as a result of IL-6 action towards osteoclasts and osteoblasts differentiation. On the other hand, IL-6 plays a positive regulatory role in osteoclast differentiation by inducing the expression of receptor activator of nuclear factor kappa-B ligand (RANKL) on the surface of osteoblasts $[9,24,26]$.

Several signaling pathways are strongly misregulated in the synovial fibroblasts, monocytes, neutrophils, endothelial and other cells in joints of RA patients. In particular, recent studies of human rheumatic and orthopedic diseases and specific mouse models with both activating and null mutations of proteins required for the canonical Wnt signaling suggest a crucial role of this signaling pathway in the regulation of bone formation, maintenance, reparation and remodeling by regulating osteoblast and osteoclast proliferation and differentiation $[6,10,12]$. Osteoblast differentiation is predominantly supported by BMPs that are members of the transforming growth factor $\beta$ (TGF $\beta$ ) superfamily, and by Wnt proteins. Although efficient differentiation of the mesenchymal precursors to the osteo- and chondrogenic lineages requires both Wnt and BMP signaling, and the canonical Wnt pathway subsequently acts as the master regulator of osteogenesis [20].

$\mathrm{Wnt} / \beta$-catenin signaling regulates osteogenesis through multiple mechanisms. Wnts repress alternative mesenchymal differentiation pathways such as adipocyte and chondrocyte differentiation and promote osteoblast differentiation, proliferation, and mineralization activity while blocking osteoblast apoptosis. By increasing a ratio of osteoprotegerin (OPG)/RANKL, $\beta$-catenin represses osteoclastogenesis [19]. In a healthy skeleton, cortical bones' formation and resorption adjacent to joints are well balanced but the inflammatory arthritis leads to an imbalance between these processes. Bone formation is hampered by the TNF-mediated expression of inhibitors suppressing Wnt signals, whereas bone resorption is enhanced by an expression of RANKL [3] - a key factor of the osteoclast differentiation and activation.

In terms of the commitment and differentiation of the mesenchymal stem cells (MSC), there is a cooperative crosstalk between the Wnt and BMP pathways [23]. BMP signaling is crucial for skeletogenesis and homeostasis through both development and adulthood. The crosstalk between BMP and Wnt signaling is notoriously complex in all tissues, and it can be either synergistic or antagonistic, depending on the cellular context and bone is not an exception to this rule. In line with the complexity of their crosstalk, BMP and Wnt signaling have opposing effects on the osteoprogenitors, yet they seem to function, for the most part, cooperatively in the osteoblasts and osteocytes.

ISSN 1996-4536 (print) • ISSN 2311-0783 (on-line) • Біологічні Студії / Studia Biologica • 2015 • Том 9/№3-4 • C. 5-14 
Although a crucial role for canonical Wnt signaling in skeleton homeostasis has been strongly established, much remains to be discovered in respect to its fine tuning and crosstalk with other pathways in bone [2].

In our studies, we found that IL-6 inhibits activation of Wnt signaling pathway in primary human synoviocytes. Moreover, TNF $\alpha$ and IL-6 cooperatively inhibit the activation of Wnt response (O. Korchynskyi, unpublished data). The main goal of this study was to evaluate an impact of previously unrecognized negative interaction between the Wnt and IL-6 signaling pathways in skeletal tissues as a possible major mechanism leading to age- and inflammation-related destruction of bone and joints.

\section{MATERIALS}

Short (small) hairpin RNA (shRNA). ShRNA-expressing constructs are frequently used as a convenient substitution for siRNA specifically targeting gene expression that allows to avoid initial side effects of transfection required for siRNA delivery to the cells. A set of validated shRNA lentiviral constructs that specifically target the expression of mouse versions of IL-6 mRNAs, was purchased as a part of MISSION library from Sigma-Aldrich (St. Louis, MS, U.S.A.).

Plasmids expressing BMP2 and BMP7 full-length cDNA were purchased from Open Biosystems/GE Healthcare (Lafayette, CO, U.S.A). Wnt signaling-specific reporter Bat-Luc was kindly provided by Dr. Stefano Piccolo. BMP2, BMP7 and Bat-Luc adenoviruses were prepared and grown essentially as before [7]. Briefly: to generate the BMP2 and BMP7 adenoviruses the full-length cDNA were recloned into pShuttle-CMV plasmid. A pShuttle vector was used in order to make a Bat-Luc reporter adenovirus. Obtained pShuttle or pShuttle-CMV constructs were linearized with Pmel restrictase and recombined with Easy-1 vector. Resulting cosmids were linearized with Pacl restrictase and prepared as adenoviruses in HEK-293 cells [7].

\section{METHODS}

Cell culture and ligands. Our studies were performed using mouse mesenchymal precursor cells of $\mathrm{C} 2 \mathrm{C} 12$ and KS483 lines. These cells were cultured in Dulbecco's modified Eagle's medium (DMEM, Sigma) containing $10 \%$ fetal calf serum (FCS, Sigma). Cells were grown in a $5 \% \mathrm{CO}_{2}$-containing atmosphere at $37{ }^{\circ} \mathrm{C}$. Upon transient transfection, cells were grown in DMEM supplemented with $4 \%$ FCS and 16 hours later, they were transferred to fresh DMEM with $10 \%$ FCS and addition of appropriate ligands. In particular, cells in appropriate variants were treated with $10 \mathrm{ng} / \mathrm{ml}$ of recombinant TNF $\alpha, 100 \mathrm{ng} / \mathrm{ml}$ of IL-6 in combination with $500 \mathrm{ng} / \mathrm{ml}$ of soluble IL-6R. All ligands were purchased from R\&D Systems (Minneapolis, MN, U.S.A.).

Primary human synoviocytes (fibroblast-like synoviocytes, FLS) were isolated from synovial biopsies of patients with RA $(n=18)$ fulfilling the American College of Rheumatology revised criteria for RA [1, 7], cultured as previously described [13] and used for experiments between passages 4 and 9, following overnight culture in medium containing $1 \%$ fetal bovine serum (FBS; Invitrogen, Breda, The Netherlands).

Transient transfection. C2C12 and KS483 cells were split at a density of $1.5 \times 10^{4}$ cells per $\mathrm{cm}^{2}$ in 12-well plates. Next day, cells were transiently transfected with plasmid constructs expressing shRNA targeting IL-6 mRNA or control scrambled shRNA $(0.5 \mu \mathrm{g}$ of total DNA per well). Transfection was carried out using GeneJuice transfection reagent (Merck Millipore, U.S.A.) following the manufacturer's protocol. An efficacy of

ISSN 1996-4536 (print) • ISSN 2311-0783 (on-line) • Біологічні Студії / Studia Biologica • 2015 • Том 9/№3-4 • С. 5-14 
shRNA-mediated knockdown was confirmed with quantitative PCR (polymerase chain reaction) and varied from 6.5 to 8 times for most efficient variants (data not shown).

Stable infection. C2C12 cells were plated in a complete media overnight. Lentiviral particles were added at the multiplicity of infection (MOI) $=5$ and $=10$ in the presence of DEAE-dextran, and cells were incubated for 24 hours. Then, equal amount of fresh media with no lentivirus was added, and the cells were incubated for additional 24 hours. Two days later, transduced cells were selected by adding puromycin $(3-4 \mu \mathrm{g} / \mathrm{ml})$. Obtained puromycin-resistant multi-clonal cultures of $\mathrm{C} 2 \mathrm{C} 12$ cells were used for studies. These cells were tested for presence of the lentiviral p24 using ELISA, and no p24 was detected. An efficacy of shRNA knockdown was confirmed with a Real-Time RTPCR amplification (data not shown).

Induction of osteoblast differentiation. $\mathrm{C} 2 \mathrm{C} 12$ and KS483 cell lines can be induced to differentiate into osteoblasts by different BMPs, including BMP2 and BMP7. 24 hours after transient transfection, these cells lines were transduced with a combination of adenoviral constructs encoding recombinant hBMP2 and hBMP7 at the multiplicity of infection (MOI) even to 500 for each one construct [17] to induce a production of hBMP2/ hBMP7 heterodimers along with appropriate homodimers. During osteogenesis assay, C2C12 and KS483 cells were cultured in a differentiation-supporting medium supplemented with $50 \mu \mathrm{g} / \mathrm{ml}$ ascorbic acid for 4 and 10 days, respectively. Starting from day 10 upon induction of osteogenesis, KS483 cells were also supplemented with $5 \mathrm{mM}$ $\beta$-glycerophospate for next 8 days totaling in 18 days. Recombinant BMPs were a gift from Dr. K. Sampath (Curis, Inc.).

Alkaline phosphatase assay. The alkaline phosphatase activity produced by $\mathrm{C} 2 \mathrm{C} 12$ was analyzed spectrophotometrically using a m-nitrophenylphosphate ( $\pi-N P P)$, as a substrate [25]. Four days after induction of osteogenesis, the cells were washed twice with $0.4 \mathrm{ml}$ of $1 \mathrm{X}$ phosphate-buffered saline (PBS) per well. Afterwards, cells were lysed in $0.2 \mathrm{ml}$ of alkaline phosphatase (ALP) lysis buffer (10 mM glycine, $100 \mu \mathrm{M} \mathrm{MgCl}_{2}, 10 \mu \mathrm{M}$ $\mathrm{ZnCl}_{2}, 0.1 \%$ Triton X-100) per well and agitated gently for $5 \mathrm{~min}$. Then, $10 \mu$ aliquot of cell lysate was placed into a 96-well plate and ALP activity was revealed with $90 \mu \mathrm{l} /$ well of ALP assay buffer (100 mM glycine, $1 \mathrm{mM} \mathrm{MgCl}, 100 \mu \mathrm{M} \mathrm{ZnCl}_{2}$ ) supplemented with $6 \mathrm{mM}$ m-NPP (Pierce-Thermo Fisher Scientific, Grand Island, NY, U.S.A.) [25], were mixed gently and incubated at room temperature until color developed. The optical density was measured at $405 \mathrm{~nm}\left(\mathrm{OD}_{405}\right)$ in a 96-well plate reader (BioTek, Winooski, VT, U.S.A.).

Alizarin staining. Histochemical examination of mineral deposition by KS483 cells was performed using conventional staining with Alizarin Red (Sigma-Aldrich, St. Louis, MS, U.S.A.) [25]. Cellular monolayers were washed with $1 \mathrm{X}$ PBS $(0.4 \mathrm{ml} / \mathrm{well})$ and fixed in $10 \%(\mathrm{v} / \mathrm{v})$ formaldehyde at room temperature for $5 \mathrm{~min}$. The monolayers were then washed with deionized $\mathrm{H}_{2} \mathrm{O}\left(\mathrm{dH}_{2} \mathrm{O}\right)$ prior to addition of $0.4 \mathrm{ml}$ of $2 \%$ Alizarin Red $\mathrm{S}$ solution ( $\mathrm{pH}$ 5.5) per well. The plate was incubated at room temperature for 2-5 min with gentle agitation. After aspiration of the unincorporated dye, the wells were washed twice shortly with $0.4 \mathrm{ml}$ of $\mathrm{dH}_{2} \mathrm{O}$ per well and once with $3 \mathrm{ml}$ of $\mathrm{dH}_{2} \mathrm{O}$ per well while shaking for 5 and $20 \mathrm{~min}$, respectively. Then, the monolayers were stored in $1 \mathrm{ml}$ of 1 X PBS and scanned. Representative wells are shown.

BioEthics Committee Approval. All human subject samples were collected after approval by the Institutional Review Board of the Academic Medical Center/University of Amsterdam, Amsterdam, The Netherlands (Protocol MEC 07/079 \#10.17.0708) and provision of informed consent by the patients.

Statistical analysis. Statistical differences were analyzed by Student's $t$-test.

ISSN 1996-4536 (print) • ISSN 2311-0783 (on-line) • Біологічні Студії / Studia Biologica • 2015 • Том 9/№3-4 • С. 5-14 


\section{RESULTS AND DISCUSSION}

In studies performed on primary human synoviocytes, we found that both TNF $\alpha$ and its target gene IL-6 inhibit activation of Wnt signaling induced with an overexpression of Wnt3a adenovirus (Fig. 1). The inhibitory effect was more pronounced at lower level of Wnt signaling activation (correspondingly, 13 and 11 times inhibition for TNF $\alpha$ when Wnt3a was used at $\mathrm{MOI}=300$ and 500). The inhibitory effect of IL-6 was also more pronounced at lower level of Wnt signaling activation (correspondingly, 3.4 and 3.1 times inhibition for IL-6/IL-6R combination when Wnt3a was used at $\mathrm{MOI}=300$ and 500) (Fig. 1).

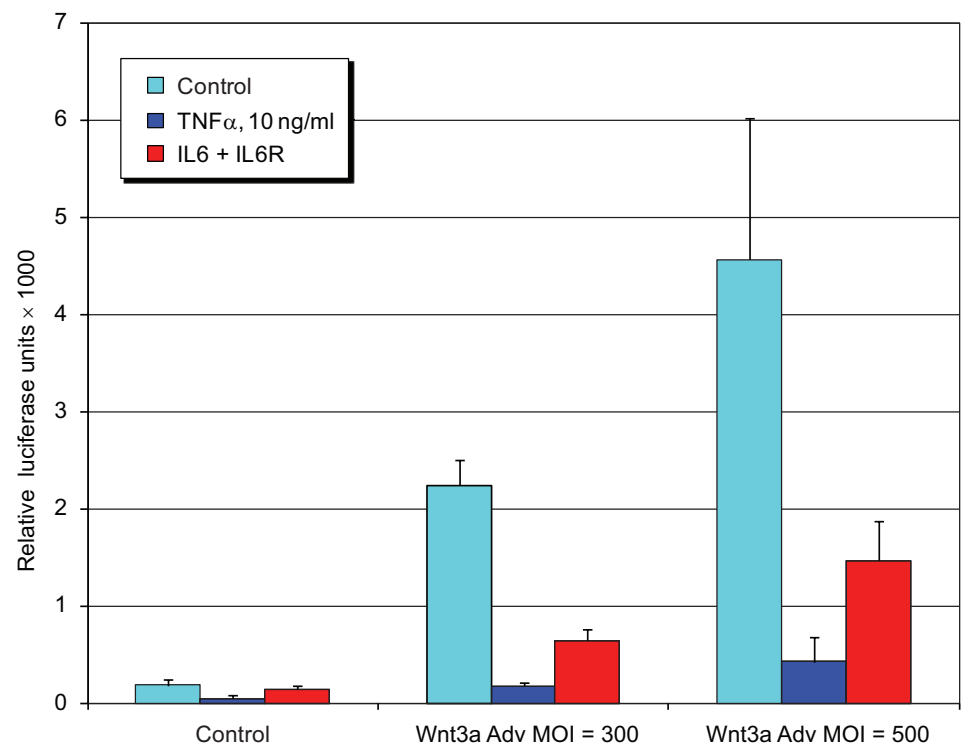

Fig. 1. IL-6 and TNF $\alpha$ inhibits activation of Wnt signaling pathway in primary synovial fibroblasts.

Primary synovial fibroblasts were transduced with the mixture of Bat-Luc luciferase reporter adenovirus at multiplicity of infection $(\mathrm{MOI})=200$ and a LacZ adenovirus $(\mathrm{MOI}=5)$ used for normalization. 10 hours later cells were treated with a combination of recombinant IL-6 (100 ng/ml) and IL-6R $(500 \mathrm{ng} / \mathrm{ml})$ or $10 \mathrm{ng} / \mathrm{ml}$ of recombinant TNF $\alpha$ for 3 days. 20 hours after reporter transduction a Wnt3a adenovirus at indicated $\mathrm{MOI}$ was infected for next 48 hours

Рис. 1. ІЛ-6 і ФНП $\alpha$ інгібують активацію сигнального шляху Wht у первинних синовіальних фібробластах.

Первинні синовіальні фібробласти трансдукували сумішшю аденовірусних конструкцій, які експресують репортерний ген люциферази Bat-Luc при множинності інфекції (MOI) = 200 i LacZ $(\mathrm{MOI}=5)$ для нормалізації. Через 10 год клітини обробляли поєднанням рекомбінантних IL-6 (100 нг/мл) i IL-6R (500 нг/мл), або 10 нг/мл рекомбінантного ФНП $\alpha$ протягом 3 днів. Через 20 год після трансдукції клітини обробляли аденовірусною конструкцією, яка експресує Wnt3a (із вказаною МOІ) протягом наступних 48 год

We further performed an in vitro evaluation of functional contribution of IL-6 and TNF $\alpha$ effect on inhibition of bone formation using treatment with recombinant cytokines combined with a blocking of IL-6 expression by shRNA in mouse mesenchymal precursor cells of C2C12. ALP is a widely used marker of early stages in osteoblast differentiation $[5,14,16]$, and we successfully used it in preliminary studies (not shown). Treatment of $\mathrm{C} 2 \mathrm{C} 12$ cells with TNF $\alpha$ completely inhibits their myoblast differentiation, as well as strongly inhibits BMP-induced osteogenesis (Fig. 2, and data not shown). 
Transient overexpression of shRNA targeting IL-6 mRNA, similarly to many other small interfering (siRNA) and shRNA, always induces some off-target interferon response. At the same time, efficient shRNA constructs allowed to partially (IL-6 shRNA-1) rescue the osteogenic differentiation from negative effect of TNF $\alpha$. In case of IL-6, shRNA-2 converts TNF $\alpha$ from an inhibitor into a potentiator of osteogenesis (data not shown).

We generated lentivirally transduced multi-clonal cultures of $\mathrm{C} 2 \mathrm{C} 12$ cells with stable expression of shRNAs that specifically targets the expression of IL-6 mRNA and scrambled shRNA. It was shown that shRNA-mediated knockdown of IL-6 expression significantly increased hBMP2/hBMP7-induced osteoblast differentiation (in individual experiments from 2.7 to 6 times compared with a control) in stable multi-clonal cultures of $\mathrm{C} 2 \mathrm{C} 12$ cells (Fig. 2).

However, ALP cannot be used as a marker for late stages of osteoblast differentiation for which bone mineral deposition and nodules formation are specific. According to literature and to our preliminary data (not shown), Wnt pathway is activated during late stages of osteoblast differentiation [18]. Unfortunately, C2C12 cells cannot undergo late stages of osteoblast differentiation. In order to confirm a proper functional outcome of IL-6 inactivation in differentiating osteoblasts, we used for these experiments KS483 cells that can efficiently follow late stages of osteogenesis [25]. Unfortunately, we were not able to combine hBMP2/hBMP7 treatment with TNF $\alpha$ due to massive death induced in KS483 cells by TNF $\alpha$ (data not shown). Similar effect was also observed by other investigators with other (pre)osteoblastic cell lines [4, 15].

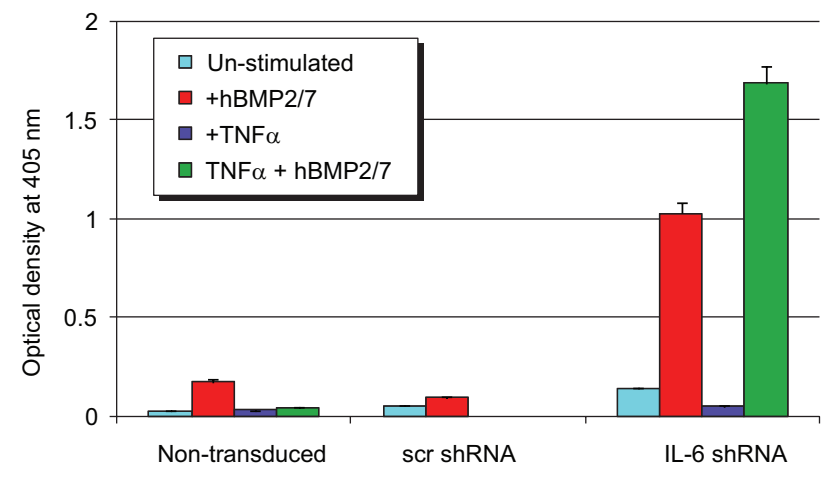

Fig. 2. ShRNA-mediated knockdown of IL-6 expression potentiates and rescues early osteogenesis from negative effect of TNF $\alpha$ in stable multi-clonal cultures of $\mathrm{C} 2 \mathrm{C} 12$ cell line.

Stable lentivirally transduced multi-clonal cultures of $\mathrm{C} 2 \mathrm{C} 12$ cells were split into 12-well plates and treated with a mixture of recombinant hBMP2 and hBMP7 adenoviruses; $10 \mathrm{ng} / \mathrm{ml}$ of recombinant TNF $\alpha$ or with their combination for 4 days. Alkaline phosphatase activity in cell lysates was analyzed spectrophotometrically. Optical density at $405 \mathrm{~nm}$ is shown

Рис. 2. ShRNA-опосередкований нокдаун експресії гена ІЛ-6 підсилює та звільняє ранні стадії остеогенезу від негативного впливу ФНП $\alpha$ у стабільних мультиклональних культурах клітин лінії С2C12.

Трансдуковані лентивірусами стабільні мультиклональні культури клітин лінії С2С12 під час культивування у 12-лункових планшетах обробляли сумішшю аденовірусних конструкцій, які експресують hBMP2 і hBMP7, рекомбінантним ФПН $\alpha$ (10 нг/мл) або їхнім поєднанням та інкубували протягом 4 днів. Активність лужної фосфатази у клітинних лізатах аналізували спектрофотометрично. Оптичну густину вимірювали при 405 нм

As is shown on a fig. 3, a treatment of KS483 cells with hBMP2/7 strongly intensified their late osteoblast differentiation and overexpression of a combination of 6 versions of shRNA constructs targeting IL-6 further potentiated osteoblast differentiation. It

ISSN 1996-4536 (print) • ISSN 2311-0783 (on-line) • Біологічні Студії / Studia Biologica • 2015 • Том 9/№3-4 • С. 5-14 
was observed through nodules formation and matrix mineralization when compared with a control scrambled shRNA.

We showed that a knockdown of IL-6 expression partially rescues osteogenesis from the negative control of inflammation. Such a result suggests that IL-6 is an important mediator in inhibition of osteoblast differentiation by TNF $\alpha$. Despite the fact that IL-6 and TNF $\alpha$ are well recognized as the key cytokines in RA pathogenesis, a proper understanding of the precise molecular mechanism(s) for functional contribution of IL-6 and TNF $\alpha$ interaction into inhibition of bone formation is critically important.

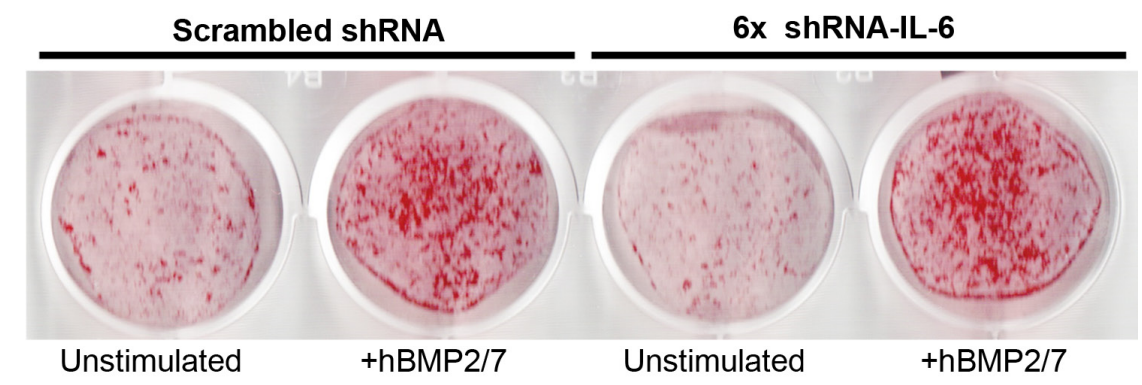

Fig. 3. ShRNA-mediated knockdown of IL-6 intensifies hBMP2/7-induced bone matrix mineralization in KS483 mouse mesenchymal precursor cells.

KS483 cells were transduced with indicated shRNA plasmids ( $0.5 \mu \mathrm{g}$ of total DNA per well). Osteoblast differentiation was triggered with a combination of adenoviral constructs encoding recombinant hBMP2 and hBMP7. During osteogenesis assay cells were cultured in a differentiation-supporting medium for 18 days. Cells were fixed and stained with Alizarin Red. Representative fields (1x) are shown

Рис. 3. ShRNA-опосередкований нокдаун експресії гена IJ-6 підсилює hBMP2/7-індуковану мінералізацію кісткового матриксу мезенхімними клітинами-попередниками миші KS483.

Клітини лінії KS483 були трансдуковані зазначеними shRNA плазмідами (0,5 мкг усієї ДНК на лунку). Остеобластну диференціацію індукували сумішшю аденовірусних конструкцій, які кодують рекомбінантні hBMP2 і hBMP7. Під час експерименту клітини культивували в диференційному середовищі протягом 18 днів. Клітини фіксували і фарбували алізариновим червоним. Відповідні поля (1x) наведені

Taking into account known data, it was unexpectedly to find TNF $\alpha$ as an activator of osteoblast differentiation. It shows that activation/inhibition and regulation of osteogenesis are poorly known, in particular during inflammation or due to aging. It is a complex system that includes many components and interactions and many of them are still unknown.

We also showed that IL-6 is an important inhibitor of late osteogenesis which can be explained by the existence of still unknown direct or indirect negative interaction between IL6 and Wnt signaling pathways. The Wnt signaling pathway inhibition by this cytokine in skeletal tissues is a possible major mechanism leading to age- and inflammation-related bone and joints destruction.

Thus, our data as well as results of other investigators together with our preliminary results allow us to hypothesize that a crosstalk between IL-6 and Wnt signaling pathways represents a novel key system in regulating homeostasis of joint tissues with involvement into pathogenesis of RA and osteoporosis progression. Our understanding of the precise molecular mechanisms and functional impact of inhibition of Wnt signaling pathway by IL-6 is crucially important for proper knowing of its role in the RA and osteoporosis pathogenesis and progression. Besides that, knowing these mechanisms can become a basis for development of novel strategies in diagnostics and treatment of this and other related disorders.

ISSN 1996-4536 (print) • ISSN 2311-0783 (on-line) • Біологічні Студії / Studia Biologica • 2015 • Том 9/№3-4 • С. 5-14 


\section{CONCLUSIONS}

IL-6 is an important mediator in inhibition of osteoblast differentiation by the TNF $\alpha$, and knockdown of IL-6 expression partially rescues osteogenesis from negative control of inflammation. The anti-osteoblastic effects of IL-6 are most likely mediated by its negative interaction with Wnt signaling pathway.

\section{ACKNOWLEGMENTS}

This work was partly supported by Young Scientist Carrier Support grant from the West-Ukrainian BioMedical Research Center (WUBMRC), and by the Molecular \& Cellular Biotechnologies Grant of the National Academy of Sciences of Ukraine (Project No 37).

1. Arnett F.C., Edworthy S.M., Bloch D.A. et al. The American Rheumatism Association 1987 revised criteria for the classification of rheumatoid arthritis. Arthritis \& Rheumatology, 1988; 31: 315-24.

2. Baron R., Kneissel M. WNT signaling in bone homeostasis and disease: from human mutations to treatments. Nature Medicine, 2013; 19(2): 179-92.

3. Diarra D., Stolina M., Polzer K. et al. Dickkopf-1 is a master regulator of joint remodeling. Nature Medicine, 2007; 13: 56-63.

4. Dong J., Cui $X$., Jiang $Z$. et al. MicroRNA-23a modulates tumor necrosis factor- $\alpha$-induced osteoblasts apoptosis by directly targeting Fas. Journal of Cellular Biochemistry, 2013; 114(12): 2738-2745.

5. Fujii M., Takeda K., Imamura T. et al. Roles of bone morphogenetic protein type I receptors and Smad proteins in osteoblast and chondroblast differentiation. Molecular Biology of the Cell, 1999; 10(11): 3801-3813.

6. Galli C., Piemontese M., Lumetti S. et al. The importance of Wnt pathways for bone metabolism and their regulation by implant topography. European Cells and Materials, 2012; 24: 46-59.

7. Grabiec A.M., Korchynskyi O., Tak P.P., Reedquist K.A. Histone deacetylase inhibitors suppress rheumatoid arthritis fibroblast-like synoviocyte and macrophage IL-6 production by accelerating mRNA decay. Annals of the Rheumatic Diseases, 2012; 71(3): 424-31.

8. Hashizume M., Mihara M. The roles of interleukin-6 in the pathogenesis of rheumatoid arthritis. Arthritis, 2011; 765624.

9. Hennigan S., Kavanaugh A. Interleukin-6 inhibitors in the treatment of rheumatoid arthritis. Therapeutics and Clinical Risk Management, 2008; 4: 767-775.

10. Issack P.S., Heflet D.L., Lane J.M. Role of Wnt signaling in bone remodeling and repair. Hospital for Special Surgery Journal, 2008; 4: 66-70.

11. Jang C.H., Choi J.H., Byun M.S. et al. Chloroquine inhibits production of TNF-alpha, IL-1beta and IL-6 from lipopolysaccharide-stimulated human monocytes/macrophages by different modes. Rheumatology, 2006; 45(6): 703-710.

12. Johnson M.L., Kamel M.A. The Wnt signaling pathway and bone metabolism. Current Opinion in Rheumatology, 2007; 19: 376-382.

13. Kasperkovitz P.V., Verbeet N.L., Smeets T.J. et al. Activation of the STAT1 pathway in rheumatoid arthritis. Annals of the Rheumatic Diseases, 2004; 63: 233-9.

14. Katagiri T., Yamaguchi A., Komaki M. et al. Bone morphogenetic protein-2 converts the differentiation pathway of $\mathrm{C} 2 \mathrm{C} 12$ myoblasts into the osteoblast lineage. The Journal of Cell Biology, 1994; 127 (6 Pt 1): 1755-1766.

15. Kitajima I., Nakajima T., Imamura T. et al. Induction of apoptosis in murine clonal osteoblasts expressed by human T-cell leukemia virus type I tax by NF-KB and TNF- $\alpha$. Journal of Bone and Mineral Research, 1996; 11(2): 200-210.

16. Korchynskyi O., Dechering K.J., Sijbers A.M. et al. Gene array analysis of bone morphogenetic protein type I receptor-induced osteoblast differentiation. Journal of Bone and Mineral Research, 2003; 18(7): 1177-1185.

17. Korchynskyi O. Adenoviral vectors: convenient tools for gene delivery to primary mammalian cells. Biotechnologia Acta, 2012; 5(5): 16-26. 
18. Krause C., Korchynskyi O., de Rooij K. et al. Distinct modes of inhibition by sclerostin on bone morphogenetic protein and Wnt signaling pathways. The Journal of Biological Chemistry, 2010; 285(53): 41614-41626.

19. Krishnan V., Bryant H.U., MacDougald O.A. Regulation of bone mass by Wnt signaling. The Journal of Clinical Investigation, 2013; 116: 1202-1209.

20. Kwan Tat S., Padrines M., Théoleyre S. et al. IL-6, RANKL, TNF-alpha/IL-1: interrelations in bone resorption pathophysiology, bone signaling pathways and treatment of osteoporosis. Cytokine and Growth Factor Reviews, 2003; 15: 49-60.

21. Mclnnes I.B., Schett G. Cytokines in the pathogenesis of rheumatoid arthritis. Nature Reviews Immunology, 2007; 7(6): 429-442.

22. Park J.Y., Pillinger M.H. Interleukin-6 in the pathogenesis of rheumatoid arthritis. Bulletin of the NYU Hospital for Joint Diseases, 2007; 65: 4-10.

23. Rawadi G., Roman-Roman S. Wnt signalling pathway: a new target for the treatment of osteoporosis. Expert Opinion on Therapeutic Targets, 2005; 9: 1063-1077.

24. Srirangan S., Choy E.H. The role of Interleukin 6 in the pathophysiology of rheumatoid arthritis. Therapeutic Advances in Musculoskeletal Disease, 2010; 2: 247-256.

25. van der Horst G., van Bezooijen R.L., Deckers M.M. et al. Differentiation of murine preosteoblastic KS483 cells depends on autocrine bone morphogenetic protein signalling during all phases of osteoblast formation. Bone, 2003; 31(6): 661-669.

26. Yoshitake F., Itoh S., Narita H. et al. Interleukin-6 directly inhibits osteoclast differentiation by suppressing receptor activator of NF-kB signaling pathways. Journal of Biological Chemistry, 2008; 283: 11535-11540.

\title{
ShRNA-OПОСЕРЕДКОВАНИЙ НОКДАУН ЕКСПРЕСІЇ ІНТЕРЛЕЙКІНУ-6 ЗВІЛЬНЯЄ ОСТЕОГЕНЕЗ МИШАЧИХ МЕЗЕНХІМНИХ СТОВБУРОВИХ КЛІТИН ВІД БЛОКУВАННЯ ФАКТОРОМ НЕКРОЗУ ПУХЛИН $\alpha$
}

\author{
Х. В. Малишева ${ }^{1,2}$, К. де Роій̈, К. Ловік \\ Д. Л. Батен \\ 1/нститут біології клітини НАН України, вул. Драгоманова, 14/16, Львів 79005, Україна \\ e-mail: olexkor@hotmail.com. \\ ${ }^{2}$ Iнститут біології тварин НААН України, вул. В. Стуса, 38, Львів 9034, Україна \\ ${ }^{3}$ Медичний центр Лейденського університету, Лейден, Нідерланди \\ ${ }^{4}$ Академічний медичний центр/Амстердамський університет, \\ відділ клінічної імунології та ревматології, Амстердам, Нідерланди
}

Ревматоїдний артрит (PA) - важке аутоімунне запальне захворювання, яке значно ускладнює життя пацієнтів, оскільки асоційоване з різними патологічними станами та соціально-економічними витратами. Етіологія цього захворювання залишається невідомою. Було показано, що інтерлейкін-6 (ІЛ-6), ген якого є мішенню дії інтерлейкіну $1 \beta$ (ІЛ-1 $\beta)$ та фрактора некрозу пухлини $\alpha(Ф Н П \alpha)$, відіграє важливу роль у патофрізіології РА. Відомо, що сигнальні ланцюги морфогенетичних білків кістки (МБК) i Wnt є ключовими сигнальними шляхами, які важливі для індукції та підтримання фрормування хрящової і кісткової тканин. Нами з'ясовано, що стимуляція первинних синовіоцитів людини ІЛ-6 подібно до ФНП $\alpha$ призводить до блокування сигнального шляху Wnt. У цій роботі зроблено оцінку впливу нововиявленої нами негативної взаємодії між сигнальними шляхами Wnt та IЛ-6 у кістках і хрящах як імовірного основного механізму, що призводить до руйнування кісток і суглобів, зумовленого віком і запаленням. Встановлено, що shRNA-опосередкований нокдаун експресії IЛ-6 значно підсилює перебіг ранніх стадій hBMP2/7-індукованого остеогенезу клітин лінії С2С12 і звільняє його від негативного впливу ФНП $\alpha$. Він також підсилює

ISSN 1996-4536 (print) • ISSN 2311-0783 (on-line) • Біологічні Студії / Studia Biologica • 2015 • Том 9/№3-4 • С. 5-14 
мінералізацію кісткового матриксу мезенхімними клітинами-попередниками миші лінії KS483. Отже, ІЛ-6 є важливим медіатором викликаного дією ФНП $\alpha$ інгібування диференціювання остеобластів. Нокдаун мРНК ІЛ-6 частково звільняє остеогенез від негативного впливу запалення. Антиостеобластні ефекти ІЛ-6, ймовірно, опосередковані його негативним впливом на сигнальний шлях Wht.

Ключові слова: ревматоїдний артрит, мезенхімні стовбурові клітини, остеогенез, інтерлейкін-6, сигнальний шлях Wnt.

\section{ShRNA-ОПОСРЕДОВАННЫЙ НОКДАУН ЭКСПРЕССИИ ГЕНА ИНТЕРЛЕЙКИНА-6 ОСВОБОЖДАЕТ ОСТЕОГЕНЕЗ ОТ БЛОКИРОВКИ ФАКТОРОМ НЕКРОЗА ОПУХОЛЕЙ $\alpha$ В МЫШИНЫХ МЕЗЕНХИМАЛЬНЫХ КЛЕТКАХ-ПРЕДШЕСТВЕННИКАХ}

Х. В. Малышева ${ }^{1,2}$, К. де Роий ${ }^{3}$, К. Ловик Д. Л. Батенн , Р. С. Стойка', О. Г. Корчинский'1,4

${ }^{1}$ Институт биологии клетки НАН Украины, ул. Драгоманова, 14/16, Львов 79005, Украина e-mail: olexkor@hotmail.com.

${ }^{2}$ Институт биологии животных НААН Украины, ул. В. Стуса, 38, Львов 79034, Украина

${ }^{3}$ Медицинский центр Лейденского университета, Лейден, Нидерланды

${ }^{4}$ Академический медицинский центр/Амстердамский университет, отдел клинической иммунологии и ревматологии, Амстердам, Нидерланды

Ревматоидный артрит (РА) - тяжелое аутоиммунное воспалительное заболевание, которое значительно осложняет жизнь пациентов, поскольку ассоциировано с различными патологическими состояниями и социально-экономическими затратами. Этиология заболевания остается неизвестной. Было показано, что интерлейкин-6 (ИЛ-6), являющийся геном-мишенью фактора некроза опухолей $\alpha$ (ФНО $\alpha)$ и интерлейкина $1 \beta$ (ИЛ-1 $\beta$ ), играет важную роль в патофизиологии РА. Известно, что сигнальные цепи морфогенетических белков кости (МБК) и Wnt являются ключевыми сигнальными путями, которые индуцируют и поддерживают формирование хрящевой и костной тканей. Нами показано, что стимуляция первичных синовиоцитов человека с помощью ИЛ-6 подобно ФНО $\alpha$ ведет к блокированию сигнального пути Wnt. B этом исследовании мы оценили влияние ранее неизвестного негативного взаимодействия между сигнальными путями Wnt и ИЛ-6 в скелетных тканях, в качестве вероятного основного механизма, который приводит к обусловленному возрастом или воспалением разрушению костей и суставов. Было показано, что shRNA опосредованный нокдаун экспрессии гена ИЛ-6 значительно усиливает ранние стадии hBMP2/7 - индуцированного остеогенеза клеток линии C2C12 и освобождает его от негативного влияния ФНО $\alpha$, а также усиливает минерализацию костного матрикса мезенхимальными клетками-предшественниками мыши KS483. Таким образом, ИЛ-6 является важным медиатором ФНО $\alpha$-опосредованного ингибирования диффреренцировки остеобластов и нокдаун гена ИЛ-6 частично освобождает остеогенез от негативного воздействия воспаления. Антиостеобластные эффекты ИЛ-6, вероятно, опосредованы его отрицательным взаимодействием с сигнальным путем Wnt.

Ключевые слова: ревматоидный артрит, мезенхимальные стволовые клетки, интерлейкин-6, остеогенез, сигнальный путь Wnt.

Одержано: 24.11.2015

ISSN 1996-4536 (print) • ISSN 2311-0783 (on-line) • Біологічні Студії / Studia Biologica • 2015 • Том 9/№3-4 • С. 5-14 